\title{
Implementation mechanism of impact investing in the post-conflict regions
}

http://doi.org/ 10.21272/fmir.4(3).53-62.2020.

Yuliya Yelnikova, ORCID: https://orcid.org/0000-0002-8478-4716

$\mathrm{PhD}$, assistant professor, Department of Accounting and Tax, Sumy State University, Sumy, Ukraine

Radoslaw Miskiewicz, ORCID: https://orcid.org/0000-0003-2370-4783

Hab. Dr., Professor, Silesian University of Technology, Gliwice, Poland

\begin{abstract}
The losses of the Ukrainian economy from the military conflict are primarily due to the powerful potential that the affected region had for the conflict, considering their synergistic effect on the development of industry, agriculture, trade and services in the country. The restoration of post-conflict regions is extremely important, given the need to ensure an acceptable level of quality of life for the population, their employment (at least temporary), restoration of local infrastructure, which requires the creation of favorable conditions and a rationale mechanism for making investments in these regions to ensure the restoration of economic stability in the country. It will be possible to say about the possibility of large-scale impact investment with the attraction of powerful private capital for the restoration of the affected regions only after the signing of the relevant government agreement that would provide protection against investment losses for investors. In the first post-conflict years, when a significant inflow of private capital cannot be expected, at least the initial conditions for the sustainable development of these territories in the medium and long term have not been formed, the main impact investors are international organizations and funds. The article examines the conditions and opportunities for impact investment in post-conflict regions of Ukraine, ways to attract foreign investment, assess the potential of impact investment for the national economy of the country, detail the mechanism of impact investment in post-conflict regions in order to rationalize the use of investment resources and minimize risks for impact investors. The article developed a matrix of SWOT-analysis of a project that claims to receive financial assistance from an impact investor for post-conflict reconstruction of regions, systematized the hierarchy of goals of an impact project, and proposed a structural and logical scheme for making decisions during its implementation. To attract impact investment, it is necessary to create an investment-friendly environment to obtain the most positive effect from investments. Taking into account that the risks can be quite high, especially at the initial stages of implementation of an impact project, any opportunities for support within the framework of the implementation of projects by other structures should be used, for example, within the framework of restoring peace in post-conflict territories, rehabilitation and reconstruction of infrastructure, etc.
\end{abstract}

Keywords: investment, reconstruction, impact investment, investment risks, post-conflict economy, economic development.

JEL Classification: G11, G19, G23, F51.

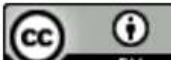

Cite as: Yelnikova, Y., Miskiewicz, R. (2020). Implementation mechanism of impact investing in the post-conflict regions. Financial Markets, Institutions and Risks, 4(3), 53-62. http://doi.org/ 10.21272/fmir.4(3).53-62.2020.

(C) The Authors, 2020. This article is published with open access at Sumy State University.

\section{Introduction}

At the end of 2013 the political crisis in Ukraine escalated into the largest military conflict in Europe since World War II. The global result was a revision of the foundations of the current system of international security, but for Ukraine the depth of consequences was more pronounced. Besides, human losses, the annexation of territories, destruction and damage to property complex, infrastructure zones of war, the existing system of relations in the field of production, trade, budget and finance has also changed since independence. The losses of the Ukrainian economy from the military conflict are related to the role of the affected regions in the development of industry, agriculture, trade and services. Stabilization of all these processes requires additional funding and recovery for further development. Accordingly, it is necessary to create favorable conditions and a rationale mechanism for the implementation of impact investment in the post-conflict economy to ensure the restoration of economic stability in the country. 


\section{Literature review}

The relevance of the assessment of the consequences of the armed conflict is considered in the works of V.V. Anisimova (2015), B.A. Karpinsky (2014), O.P. Kornienko (2015), K. M. Korniychuk (2016). Note that the work of S.F. Harkavyi (2014), E.M. Libanova (2015), O.Y. Snihova, T.Y. Zagorelska (2015), O.V. Sobkevych (2015) is devoted to the study of the economic consequences of hostilities in eastern Ukraine and their quantification.

It necessary to pay attention to the works of such authors E. Avdokushin (1996), N. Dalevska et al. (2019), W. Drozdz et al. (2019; 2020), T. Frolova (2013), P. Glowski \& O. Kvilinskyi (2017), T. Govorushko (2013), A. Kwilinski (2018; 2019; 2020a; 2020b), Lakhno et al. (2018), R. Miskiewicz (2017a; 2017b; 2018; 2019), K. Pajak et al. (2017), E. Sidorova (2008), N. Stukalo (2012), whose works cover the investment aspect, namely, international investment in the global economic environment. Given that investment is an important element in rebuilding the post-conflict economy, there is a need to study this issue and improve approaches to the implementation of impact investing in the post-conflict economy.

\section{Results}

From the point of view of impact investors, the biggest uncertainty is when to start financing the project. Here are some important points to make a final decision. First, investors need information not so much about economic characteristics as about the political environment. Second, when information is not available, investors look at external signals. Third, the post-conflict environment is characterized by a lack of objective information, so the signals are more important after the end of the conflict. Finally, receiving external assistance from international financial organization and government indicates a trust in the recipient country. That is why foreign aid for the reconstruction and development of post-conflict countries can be a useful signal for investors (or their agents) who do not have enough confidence in the feasibility of starting their own investment projects. Note that this assistance is considered only as a signal when other information is scarce or unreliable, for example, immediately after the war. This suggests that in post-conflict countries, investment should follow assistance, but only until information from other sources becomes available.

The country's foreign aid after the conflict is a useful signal to investors for two reasons. First, foreign aid is an available signal. Package assistance becomes public information through the press and is available to a global audience. This makes the signal clear to investors regardless of the donor's nationality. At the same time, the governments of post-conflict countries not only publish notices of aid programs (which can be seen regularly in the media), but also announce the refusal of aid, reduction or termination of it. In addition, declarations of assistance are often accompanied by statements of confidence in the recipient country, and sometimes accompanied by statements of intent to signal to other international actors, including investors.

Secondly, foreign aid is an expensive signal. Countries invest financial resources in accordance with their decisions on the distribution of aid, and, of course, this is a significant cost. Because aid is expensive, it is a better indicator of trust in local authorities than just declarations. The cost of the signal combined with the likely lack of reliable alternatives makes foreign aid an important indicator for potential impact investors. In addition, foreign aid often has additional conditions for disposing of funds received or special commitments in domestic or international policy areas. This type of signal is valuable for impact investors who seek information on government confidence but are unable to obtain relevant data directly from post-conflict regions.

Thus, the received and correctly interpreted signals give impact investors a specific moment to start working in the post-conflict region. The process should include standard elements:

$$
\begin{aligned}
& >\quad \text { data selection and analysis; } \\
& >\quad \text { decision making; } \\
& >\quad \text { project implementation. }
\end{aligned}
$$

Let's start with the stage of data collection and analysis. The purpose of the paper is to improve the understanding of the realities of the post-conflict economy, which in turn leads to the right management decisions. The results of the analysis are used to inform those responsible for decision-making on project initialization, inform local stakeholders about the potential results of the project in order to involve them in the project, form recommendations on regional development strategy, identify new opportunities, risks, potential problems, monitor further progress. stages of practical implementation of the project. The general profiling of the region is 
the starting element of the work and includes the collection of information in the following areas:

$>\quad$ territory of post-conflict reconstruction;

$>\quad$ the level of intervention of other countries in the conflict;

$>\quad$ current issues that remain unresolved (ideological component of the conflict, religious barriers, formation of local authorities, state control over the conflict territory);

$>$ factors that may exacerbate / hinder the development of the conflict;

$>\quad$ identification of the parties to the conflict, their goals and characteristics;

$>\quad$ stage of conflict development;

$>\quad$ specific features of the post-conflict territory.

The next step should be an initial assessment of the region's economy. This allows you to specify the territorial boundaries of the project, the population groups on which the project is aimed, to make economic segmentation, to determine the priorities of the initial stages of the project. The result is the concretization of the economic context of the region's development, the impact of the conflict on jobs, markets and various types of economic activity. It is worth noting the current programs that are already in the process of implementation. It is necessary to conduct the initial identification of project stakeholders. At the initial stage, it is enough to identify the groups of the most active, influential participants, as well as individuals who can become potential allies in the project and those who can create resistance to the planned actions.

An important stage of preliminary work is the assessment of local procurement opportunities necessary for the implementation of the project goods and services. This not only contributes to the achievement of the project objectives, but also encourages the resumption of local business activity, the creation of new jobs in the relevant supply chains. This is particularly important in view of the fact that financial resources for local reconstruction will still be spent for these purposes and therefore there is no need to attract additional sources of funds. Therefore, after finalizing the initial assessment of regional features, it is necessary to move to a detailed profiling of the local economy, highlighting such key areas as human resources, natural resources, physical infrastructure and assets, economic and social capital. This provides an opportunity to identify areas for job creation, private sector recovery, and key areas for socio-economic recovery. The information required for the economic profiling of the region should include the elements listed in Table 1.

Table 1. Elements of economic profiling of the region

\begin{tabular}{|l|c|}
\hline \multicolumn{1}{|c|}{ Group } & \\
\hline General indicators & $>\quad$ typology of the territory (urban / rural); \\
\hline People & $>\quad$ level of economic integration (isolated / integrated); \\
\hline Natural resources & $>\quad$ the level of development of the private sector of the economy (low, medium, high). \\
\hline Physical capital & $>\quad$ basic demography; \\
\hline Institutional capital & $>\quad$ ethnic composition of the population; \\
\hline Economic capital & $>\quad$ the number of participants in hostilities; \\
\hline Social capital & $>\quad$ number of migrants (forcibly displaced persons); \\
\hline Current programs and projects & $>$ gender structure of the population; \\
\hline
\end{tabular}

Source: compiled by the author.

The last step of profiling is the presentation of accumulated data and estimates in the form of a consolidated report with specific conclusions and recommendations. Based on the report, stakeholders responsible for decision-making select key areas and areas of implementation of the impact project. Data collected during the profiling process may be insufficient or individual indicators may require additional information to more accurately identify regional features, they should also be collected and the information displayed separately. In the future, impact investors can draw conclusions about the feasibility of the project on the basis of SWOTanalysis. A potential list of questions is given in Table 2.

Table 2. Matrix of SWOT-analysis of a project that applies for financial assistance from an impact investor

\begin{tabular}{|l|l|}
\hline \multicolumn{1}{|c|}{ Strengths } & \multicolumn{1}{|c|}{ Weaknesses } \\
\hline What are the most important resources of the territory? & $\begin{array}{l}\text { What are the main commitments that can limit the achievement of } \\
\text { economic recovery? }\end{array}$ \\
\hline What are the opportunities to maximize the return on these resources? & What is the biggest weakness or problem of the region? \\
\hline $\begin{array}{l}\text { What resources with financial support can be important for the } \\
\text { territory? }\end{array}$ & $\begin{array}{l}\text { What problems do residents face when interacting with local } \\
\text { authorities and other structures? }\end{array}$ \\
\hline
\end{tabular}

Source: compiled by the author. 
In the process of implementing the measures developed within the framework of the impact project, the information should be updated to monitor progress and achieve goals. A key element of this process is the comparison of intermediate goals with the established reference indicators, calculated efficiency indicators. The reasons for deviations from the planned results must be identified and eliminated for further progress and effectiveness of the impact project. Example of such indicators may be the following (Table 3.)

Table 3. Examples of indicators for monitoring the current results of the impact project

\begin{tabular}{|c|c|}
\hline Example of results & Example of indicators \\
\hline \multicolumn{2}{|r|}{ Impact project } \\
\hline $\begin{array}{l}\text { Groups involved in military conflict are economically } \\
\text { reintegrated and coexist in a peaceful environment }\end{array}$ & $\begin{array}{l}\text { Reduction of social tension at the level of local communities (number of recorded } \\
\text { conflict situations per month - decrease in the value of the indicator) }\end{array}$ \\
\hline \multicolumn{2}{|r|}{ ( } \\
\hline $\begin{array}{l}\text { Result } 1 . \\
\text { Market linkages have been restored and improved to meet } \\
\text { the needs of the local market for goods and services }\end{array}$ & $\begin{array}{l}\text { Number of regionally produced products (by category) available in local markets } \\
\text { shops } \\
\text { Average number of clients and regional service providers }\end{array}$ \\
\hline $\begin{array}{l}\text { Result } 2 . \\
\text { In the regional economy, temporary and permanent jobs } \\
\text { have been created for local workers }\end{array}$ & $\begin{array}{l}\text { Number of working days generated on a monthly basis by regional economic agents } \\
\text { Number of people who found a job }\end{array}$ \\
\hline \multicolumn{2}{|r|}{ Initial indicators } \\
\hline $\begin{array}{l}\text { 1. The transport network provides effective } \\
\text { communication between settlements }\end{array}$ & $\begin{array}{l}\text { Number of kilometers of roads, tunnels, bridges built / restored } \\
\text { Cost } 1 \mathrm{~km} \text { (by object types) } \\
\text { Travel time from point A to point B }\end{array}$ \\
\hline $\begin{array}{l}\text { 2. Supply chains for regional products / services have } \\
\text { been improved, products have increased added value }\end{array}$ & $\begin{array}{l}\text { Average distance to be purchased for the purchase of raw materials }(\mathrm{km}) \\
\text { Gross profit of local companies } \\
\text { Share sales of local companies }\end{array}$ \\
\hline 3. Local producers are more productive & $\begin{array}{l}\text { Profit of local companies per } 1 \text { employee } \\
\text { Number of new businesses created after passing specialized courses / trainings } \\
\text { Number of new products / services offered by local companies }\end{array}$ \\
\hline 4. Local companies create new jobs & $\begin{array}{l}\text { Average number of employees } \\
\text { Number of working days per month (including temporary workers) }\end{array}$ \\
\hline
\end{tabular}

Source: Compiled by the author.

The next step after gathering the necessary information, preparing reports is to decide on the feasibility of the project, taking into account the availability of the necessary financial and human resources. At the same time, it is necessary to determine the territory of the impact project implementation, the economic sector and the beneficiaries. The solution is quite simple if you need to consider only one criterion or there are no alternatives, doubts, differences between stakeholders. The complexity of the problem that the impact project is aimed at solving requires compromise solutions, makes it impossible to solve all its aspects, and must take into account the potential dissatisfaction of individual stakeholders.

The process of making a final decision does not have the opportunity to get a single and correct answer in case of complex problems, however, you should choose a method that will justify it. Among the available alternatives are the method of quantitative multi-criteria decision-making and the method of scenario planning. The methods are not necessarily mutually exclusive and can complement each other. The first method involves choosing from a list of alternatives, which are ranked according to their final score, as the sum of the scores of alternatives by individual criteria. The second method is suitable for environments with constantly changing conditions, a large number of variables and a high level of uncertainty. Therefore, its focus is on future changes in the environment rather than on past experience (as in the case of quantitative assessments).

Despite the differences, the methods involve the following steps:

$>\quad$ determining the purpose and modality of the decision-making process;

$>\quad$ selection of components (components) of the problem;

$>\quad$ understanding the correlation between different factors;

$>\quad$ obtaining and processing relevant information;

$>\quad$ data analysis and decision making.

It is necessary to make sure that the elements of post-conflict reconstruction have been implemented:

$>$ logistics and security for the beneficiaries of the impact project are sufficient;

$>$ peace negotiations are in the final stages or completed by the signing of an armistice, the process of national reconciliation has been initiated and there is the political will to succeed in this;

$>$ there is mutual understanding in the peaceful settlement by national and international players;

$>$ the processes of strengthening state power in the post-conflict territory have begun and have visible results;

$>$ humanitarian and post-conflict reconstruction organizations are present in the region and actively working; 
Donors are willing to support economic recovery programs, including in the areas of increasing employment.

The structural and logical scheme of decision-making on the implementation of the impact project is shown in Figure 1.

In general, the coordination of the project and the interaction between stakeholders determines not only whether the decision to implement an impact project will be positive, but also the further success of the whole event. Partners must share the same values and pursue the overall goal of the impact project. The stakeholder interest team ideally includes the following participants:

$>\quad$ organizations that provide assistance (UN agencies, NGOs, donors): initiate and support the impact project, mobilize resources, provide technical assistance;

$>\quad$ representatives of higher authorities (government, ministries, government agencies - macro level): provide permits to operate in selected areas, form a communication infrastructure, establish partnerships with other participants, determine or review state policies and regulations relating to project implementation, redistribute resources;

$>\quad$ Representatives of local authorities (governors, local councils, decentralized commissions - meso level): the role is similar to higher authorities, provide additional coordination / interaction at the local level within their powers;

local communities, leaders, authorities - micro level: coordination of interaction between stakeholders, implementation of the impact project strategy on the ground.

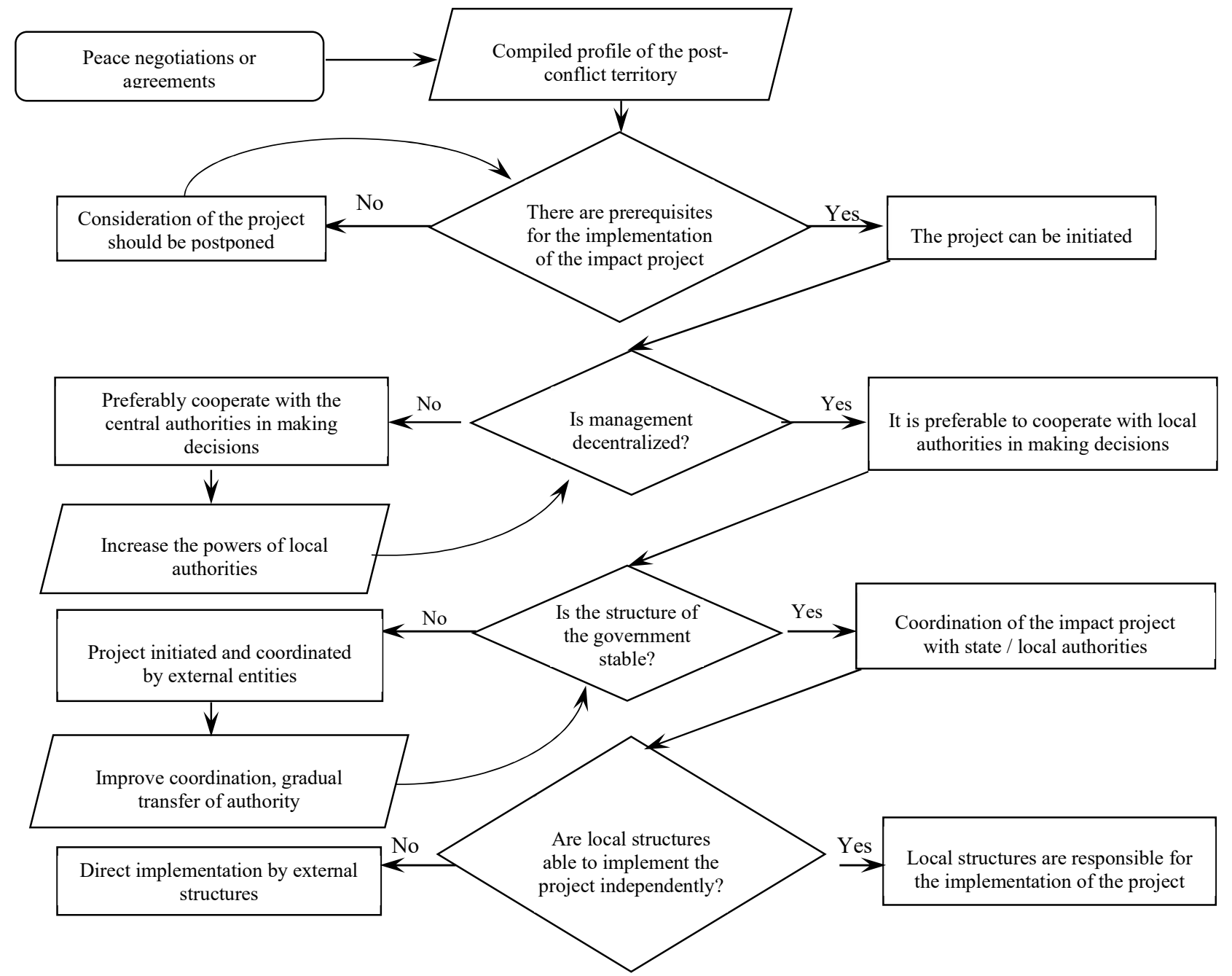

Figure 1. Structural and logical scheme of decision-making on the implementation of the impact project

Source: compiled by the author. 
Achieving the goal of the impact project requires the establishment of intermediate goals, which must be defined in advance. An example of such a distinction is shown in Table 4.

Table 4. Goals of the impact project post-conflict reconstruction of the region.

\begin{tabular}{|c|c|c|c|c|}
\hline \multicolumn{5}{|c|}{$\begin{array}{l}\text { Impact project: socio-economic reintegration of households affected by the military conflict through the creation of favorable conditions for } \\
\text { job creation, decent work, training of the workforce }\end{array}$} \\
\hline \multirow{2}{*}{\multicolumn{5}{|c|}{ Objective: to intensify and restart strategic areas of the local economy, trade, reform economic ties at the local and interregional level }} \\
\hline & & & & \\
\hline $\begin{array}{l}\text { More efficient production } \\
\text { in areas that ensure the } \\
\text { availability of key and } \\
\text { most profitable products }\end{array}$ & $\begin{array}{l}\text { Expansion of markets / } \\
\text { sales volumes of local } \\
\text { products through } \\
\text { increasing the purchasing } \\
\text { power of the population, } \\
\text { efficient operation of } \\
\text { distribution networks }\end{array}$ & $\begin{array}{l}\text { Greater transparency of } \\
\text { administrative and fiscal } \\
\text { systems, improved access } \\
\text { to information for business } \\
\text { structures and self- } \\
\text { employed }\end{array}$ & $\begin{array}{l}\text { Reduced and adjusted } \\
\text { stability control of } \\
\text { business structures in } \\
\text { vibrating spheres injected }\end{array}$ & $\begin{array}{lr}\text { Diversification and } \\
\text { forgiveness access to } \\
\text { financial instruments }\end{array}$ \\
\hline \multicolumn{5}{|l|}{ Examples: } \\
\hline $\begin{array}{l}\text { Agriculture, processing of } \\
\text { agricultural products }\end{array}$ & $\begin{array}{l}\text { Restoration of the road } \\
\text { network } \\
\text { Supply and circulation of } \\
\text { goods }\end{array}$ & $\begin{array}{l}\text { Simplification of fiscal and } \\
\text { administrative procedures / } \\
\text { services } \\
\text { Transparency and control }\end{array}$ & $\begin{array}{ll}\text { Services for } & \text { business } \\
\text { development } & \\
\text { Improving } & \text { business } \\
\text { management } & \\
\text { competencies } & \\
\text { Cooperatives, } & \\
\text { associations } & \end{array}$ & $\begin{array}{l}\text { Availability of financial } \\
\text { instruments and financial } \\
\text { services } \\
\text { Loans } \\
\text { Savings }\end{array}$ \\
\hline
\end{tabular}

Source: compiled by the author.

The implementation of the impact project should take place subject to a number of important principles and stages of work. In particular, the achievement of the set goals is possible provided that all stakeholders have a clear understanding of how the project goal will be achieved. Therefore, the promotion of the key objectives of the project at all levels (state, local) is an integral part of its implementation. Meetings, seminars, field visits and other forms of dialogue between stakeholders are used for this purpose, accompanied by reports, press releases, interviews and publications in the media, preparation of brochures and presentation materials.

Investment is a critical factor in the success of a project. Given that the risks can be quite high, especially in the initial stages of implementation of an impact project, any opportunities for accompanying support should be used in the implementation of projects by other structures, such as peace restoration in post-conflict areas, reconstruction and reconstruction of infrastructure. etc. The main investment channels include:

$>\quad$ direct investments from participating agencies;

$>\quad$ fundraising through local donors;

$>\quad$ multi-channel mobilization through related projects;

$>\quad$ resources from private and public sources of funds.

In the future, the project should be implemented according to a phased plan, starting with activities that in the short term give visible results with a gradual shift to the stages of achieving medium and long-term goals. At the same time, the number of stakeholders involved in the project should increase, especially after summarizing the results of the initial stage, opening new opportunities in the following stages.

Achieving medium- and long-term goals lays the foundation for sustainable development of the region in the future. Therefore, the involvement of local stakeholders in the implementation of the project is extremely important. This should be accompanied by the increase of competencies necessary for mastering new professions, improving existing knowledge. Examples of medium-term goals and methods of their implementation are given in Table 5.

Table 5. Medium-term goals and methods in the field of increasing employment in post-conflict areas

\begin{tabular}{|l|l|l|}
\hline \multicolumn{1}{|c|}{ Direction } & \multicolumn{1}{|c|}{ Purposes } & \multicolumn{1}{|c|}{ Methods } \\
\hline Employment & $\begin{array}{l}\text { Ensure that you have technical and professional skills } \\
\text { that are in demand in the labor market in order to } \\
\text { increase employee productivity. }\end{array}$ & $\begin{array}{l}\text { Short-term trainings to meet the current needs of the } \\
\text { labor market. } \\
\text { Implementation / revision of training programs } \\
\text { (retraining) (in the medium term) } \\
\text { Assistance to training program providers } \\
\text { Implementation / improvement of employment centers }\end{array}$ \\
\hline
\end{tabular}


Table 5 (cont.). Medium-term goals and methods in the field of increasing employment in post-conflict areas

\begin{tabular}{|c|c|c|}
\hline Entrepreneurship & $\begin{array}{l}\text { Formation and promotion of entrepreneurial culture } \\
\text { "Decent work" as a key value of entrepreneurial } \\
\text { activity } \\
\text { Improving cooperation between entrepreneurs, } \\
\text { development of management skills, dissemination of } \\
\text { technical knowledge }\end{array}$ & $\begin{array}{l}\text { Introduction of the subject "Fundamentals of Business" } \\
\text { in the school curriculum } \\
\text { Targeted trainings for beginning entrepreneurs } \\
\text { Technical support from specialized providers } \\
\text { Creation and development of the cooperative movement }\end{array}$ \\
\hline $\begin{array}{l}\text { Formation of the business } \\
\text { environment }\end{array}$ & $\begin{array}{l}\text { Formation of the environment (regulatory and } \\
\text { normative acts, development of the corresponding } \\
\text { state / local policy, transparency of conditions / } \\
\text { requirements) which promotes establishment of new } \\
\text { business structures and development of already } \\
\text { existing }\end{array}$ & $\begin{array}{l}\text { Assistance in the analysis and revision of regulations to } \\
\text { eliminate bottlenecks (registration procedures, tenders, } \\
\text { corruption) and create incentives for SMEs (taxation, } \\
\text { protection of property rights, etc.) }\end{array}$ \\
\hline Access to financial resources & $\begin{array}{l}\text { Ensure the availability and opportunities of access to } \\
\text { financial services and products for startups and } \\
\text { business development in post-conflict areas }\end{array}$ & $\begin{array}{l}\text { Distribution of grants, financial support for the } \\
\text { restoration of stocks, equipment, jobs } \\
\text { Liability guarantees for SMEs } \\
\text { Trainings and technical assistance to financial } \\
\text { institutions in the development of new products, } \\
\text { improvement of services and increasing the presence in } \\
\text { post-conflict areas }\end{array}$ \\
\hline Supporting infrastructure & $\begin{array}{l}\text { Ensure that the necessary infrastructure (transport, } \\
\text { communications, warehouses, markets, etc.) is } \\
\text { available, accessible and maintained at a level } \\
\text { sufficient for their effective functioning }\end{array}$ & $\begin{array}{l}\text { Trainings and technical assistance to entrepreneurs in } \\
\text { the field of infrastructure construction } \\
\text { Private / public construction works }\end{array}$ \\
\hline $\begin{array}{l}\text { Access to services that } \\
\text { promote business development }\end{array}$ & $\begin{array}{l}\text { Improving the competitiveness of local companies in } \\
\text { strategic sectors of the economy, access to business } \\
\text { opportunities in post-conflict areas } \\
\text { Stimulating innovation as a source of increasing the } \\
\text { competitiveness of companies and their survival in } \\
\text { harsh market conditions }\end{array}$ & $\begin{array}{l}\text { Trainings and technical assistance in business } \\
\text { management } \\
\text { Preparation of training / information sources for making } \\
\text { critical business decisions } \\
\text { Providing easy access to business development services } \\
\text { within the region }\end{array}$ \\
\hline
\end{tabular}

Source: compiled by the author.

Consider one of the impact projects related to the consequences of the military conflict in Donbass (Table 6). This example shows that project work can be carried out even before the final settlement of the conflict.

Table 6. Example of an impact project within the post-conflict reconstruction of Ukraine economy

\begin{tabular}{|l|l|}
\hline Project & Rapid response to social and economic problems internally displaced persons in Ukraine \\
\hline The purpose of the project & Restoration of IDPs in new places of residence, if possible - reintegration into their places of residence \\
\hline Project goals & 1. Strengthen the government's capacity to plan, manage and coordinate IDP issues at the national and local levels. \\
& 2. Improving the living conditions of IDPs by providing them with jobs and social services. \\
3. Promoting social inclusion, reconciliation and integration / reintegration of IDPs in resettlement areas
\end{tabular}

Source: compiled by the author.

Such projects usually involve a moderate amount of investment, which is due in this case to the fact that the military conflict in Ukraine continues, but at the same time is territorial limited. This provides an opportunity to work in the regions controlled by the Government of Ukraine, to provide assistance to those affected by the conflict at a level sufficient to meet their needs with the full cooperation and support of the state.

\section{Conclusions, discussions and recommendations}

Finally, we can talk about the feasibility of large-scale impact investment only after the signing of agreement due to the high risk of losing any results in the event of a long-term conflict. At the same time, it is impossible to count on significant amounts of financial support in the first years from private capital, and attention should be paid to sources of funds coming from international organizations and NGOs. This will provide an 
opportunity to solve current problems, especially in the field of restoring the living standards of the population by ensuring their employment in temporary jobs, mainly in the field of infrastructure rehabilitation. Only after these steps can we talk about the implementation of large projects involving private capital, the creation of new jobs and laying the conditions for further sustainable development of the region in the medium and long term.

Author Contributions: conceptualization, Yuliia Yelnikova; methodology, Yuliia Yelnikova; validation, Yuliia Yelnikova; formal analysis, Radoslaw Miskiewicz; investigation, Radoslaw Miskiewicz; resources, Radoslaw Miskiewicz; data curation, Radoslaw Miskiewicz; writing - original draft preparation, Radoslaw Miskiewicz; writing - review and editing, Yuliia Yelnikova; visualization, Radoslaw Miskiewicz; supervision, Yuliia Yelnikova; project administration, Radoslaw Miskiewicz; funding acquisition, Yuliia Yelnikova.

\section{Funding}

Material is prepared within the GDR "Modeling and forecasting of socio-economic and political road map for reform in Ukraine to move to a model of sustainable growth" (applied research, carried out at the expense of the state budget, 2018, the Ministry of Education and Science of Ukraine, number of state registration : $0118 \mathrm{U} 003569$.

\section{References}

1. Definition of «Impact Investing». (2019). Retrieved from: http://www.investopedia. com/terms/i/impact-investing.asp

2. Glenn, Russell W. (2009). Thoughts on «Hybrid» Conflict, In Small Wars Journal. Retrieved from: https://smallwarsjournal.com/blog/journal/docs-temp/188-glenn.pdf?q-\%20=mag/docs-temp/188-glenn.pdf

3. Ukraine - EC, Humanitarian Aid and Civil Protection. (2020). Retrieved from: https://ec.europa.eu/echo/where/europe/ukraine en

4. Avdokushin, Y. F. (1996). Mezhdunarodnyye ekonomicheskiye otnosheniya: ucheb. posobiye. Moskva: IVTS «Marketing». 196. [ Avdokushin E. F. (1996). International economic relations: textbook. allowance. Moscow: ITC "Marketing". 196]. Retrieved from: http://enbv.narod.ru/text/Econom/avdokushin$\underline{\text { meo/index.html }}$

5. Anisimov, V.V. (2015). Komertsiyni banky v umovakh aneksiyi Krymu Rosiys'koyu Federatsiyeyu. Finansovyy prostir. 4, 19-26. [ Anisimov, V.V. (2015). Commercial banks in the annexation of Crimea by the Russian Federation. Financial space. 4, 19-26]. Retrieved from: http:/www.irbis-nbuv.gov.ua/cgibin/irbis nbuv/cgiirbis 64.exe?I21DBN=LINK\&P21DBN=UJRN\&Z21ID=\&S21REF=10\&S21CNR=20\&S $21 \mathrm{STN}=1 \&$ S21FMT $=\overline{A S P} \_$meta\&C21COM=S\&2 S21P03=FILA=\&2 S21STR=Fin $\_p r 2015 \_4 \_4$

6. Biryukov, D.S. (2014). Zabezpechennya instytutsiynykh osnov pidtrymky pryynyattya rishen' shchodo poperedzhennya, reahuvannya ta likvidatsiyi naslidkiv nadzvychaynykh sytuatsiy: analitychna zapyska. [ Biryukov, D.S. Providing the institutional framework to support decision-making on emergency prevention, response and response: an analytical note]. Retrieved from: http://www.niss.gov.ua/articles/1534

7. Dalevska, N., Khobta, V., Kwilinski, A., \& Kravchenko, S. (2019). A model for estimating social and economic indicators of sustainable development. Entrepreneurship and Sustainability Issues, 6(4), 1839-1860. https://doi.org/10.9770/jesi.2019.6.4(21)

8. Drozdz, W., Miskiewicz, R., Pokrzywniak, J., \& Elzanowski, F. (2019). Urban Electromobility in the Context of Industry 4.0. Torun: Wydawnictwo Adam Marszalek.

9. Drozdz, W., Marszalek-Kawa, J., Miskiewicz, R., \& Szczepanska-Waszczyna, K. (2020). Digital Economy in the Comporary World. Torun: Wydawnictwo Adam Marszalek.

10. Głowski, P., \& Kvilinskyi, O. (Eds.). (2017). Economic transformation in Ukraine: comparative analysis and European experience. Warsaw: Consilium Sp. z o.o.

11. Harkavyy S.F. (2014). Eskalatsiya konfliktu na skhodi Ukrayiny: sotsial'no-ekonomichni naslidky. Finansovyy prostir, 4, 40-46. [Harkavy, S.F. (2014). The escalation of the conflict in eastern Ukraine: socioeconomic consequences. Financial space, 4, 40-46]. Retrieved from: http://www.irbis-nbuv.gov.ua/cgibin/irbis nbuv/cgiirbis 64.exe?I21DBN=LINK\&P21DBN=UJRN\&Z21ID $=\& S 21 \mathrm{REF}=10 \& \mathrm{~S} 21 \mathrm{CNR}=20 \& \mathrm{~S}$ $21 \mathrm{STN}=1 \& \mathrm{~S} 21 \mathrm{FMT}=\overline{\mathrm{ASP}} \_$meta\&C $21 \mathrm{COM}=\mathrm{S} \& 2 \_\mathrm{S} 21 \mathrm{P} 03=\mathrm{FILA}=\& 2 \_\mathrm{S} 21 \mathrm{STR}=$ Fin $\_$pr $2014 \_4 \_7$ 
Financial Markets, Institutions and Risks, Volume 4, Issue 3, 2020 ISSN (online) - 2521-1242 ISSN (print) - 2521-1250

12. Hovorushko, T. A., Obushna, N. I. (2013). Sutnist' pryamykh inozemnykh investytsiy ta yikh klasyfikatsiya. Teoriyi mikro-makroekonomiky, 41, 91-99. [Govorushko TA, Obushna NI (2013). The essence of foreign direct investment and their classification. Theories of Micro-Macroeconomics, 41, 91-99]. Retrieved from: http://dspace.nuft.edu.ua/jspui/bitstream/123456789/10871/1/20134.pdf

13. Skott, D.G. (1991). Konflikty. Puti ikh preodoleniya. Kiyev, «Vneshtorgizdat». [Scott, D. G. (1991). Conflicts. Ways to overcome them]. Retrieved from: https://search.rsl.ru/ru/record/01001611512

14. Karpins'kyy, B.A. (2014). Finansovo-resursni vtraty Ukrayiny vid diy derzhavy-aneksora (chastyna I). Naukovyy visnyk Ukrayiny, 24(5), 199-208. [ Karpinsky, B.A. (2014). Financial and resource losses of Ukraine from the actions of the annexing state (part I). Naukovyy visnyk of Ukraine, 24(5), 199-208. Retrieved from: https://nv.nltu.edu.ua/Archive/2014/24 5/nv 24 5.pdf

15. Kachyns'kyy A. B. (2013). Indykatory natsional'noyi bezpeky: vyznachennya ta zastosuvannya yikh hranychnykh znachen'. Stratehichni priorytety, 4, 200-201. [Kaczynski AB (2013). National security indicators: definition and application of their limit values. Strategic Priorities, 4, 200-201]. Retrieved from: http://nbuv.gov.ua/UJRN/spa_2013 4 _30

16. Korniyenko K.M. (2015). Perspektyvy rozvytku portovoyi haluzi Ukrayiny za umov aneksiyi Krymu. Hlobal'ni ta natsional'ni problemy ekonomiky, 8, 181-183. [ Kornienko, K.M. (2015). Prospects for the development of the port industry of Ukraine under the conditions of annexation of Crimea. Global and National Economic Problems, 8, 181-183]. Retrieved from: http://global-national.in.ua/issue-8-2015/16vipusk-8-listopad-2015-r/1413-kornienko-k-m-perspektivi-rozvitku-portovoji-galuzi-ukrajini-za-umovaneksiji-krimu

17. Korniychuk, O.P. (2016). Poryadok obrakhunku vtrat sotsial'no-ekonomichnoho potentsialu Ukrayiny, sprychynenykh okupatsiyeyu Donbasu ta aneksiyeyu Krymu. Ekonomika ta pravo, 2, 118-123. [Korniychuk OP (2016). The procedure for calculating the losses of socio-economic potential of Ukraine caused by the occupation of Donbass and the annexation of Crimea. Economics and Law, 2, 118-123]. Retrieved from: http://www.irbis-nbuv.gov.ua/cgi-bin/irbis nbuv/cgiirbis 64.exe?I21D BN=LINK\& P21DBN $=$ UJR N\&Z21ID $=\& S 21 R E F=10 \& S 21 C N R=20 \& S 21 \mathrm{ST} N=1 \& S 21 \mathrm{FMT}=\mathrm{ASP}$ meta\&C21 COM= $\underline{\mathrm{S} \& 2}$ S21P03=FILA=\&2 S21STR=ecprec $2016 \quad 2 \quad 20$

18. Kwilinski, A. (2018). Mechanism of modernization of industrial sphere of industrial enterprise in accordance with requirements of the information economy. Marketing and Management of Innovations, 4, 116-128. http://doi.org/10.21272/mmi.2018.4-11

19. Kwilinski, A., Pajak, K., Halachenko, O., Vasylchak, S., Pushak, Ya., \& Kuzior, P. (2019). Marketing Tools for Improving Enterprise Performance in the Context of Social and Economic Security of the State: Innovative Approaches to Assessment. Marketing and Management of Innovations, 4, 172-181. http://doi.org/10.21272/mmi.2019.4-14

20. Kwilinski, A., Litvin, V., Kamchatova, E., Polusmiak, J., \& Mironova, D. (2020a). Information Support of the Entrepreneurship Model Complex with the Application of Cloud Technologies. Journal of Entrepreneurship Education, 23(SI1), 1-9. Retrieved from https://www.abacademies.org/articles/Informationsupport-of-the-entrepreneurship-1528-2651-23-S1-557.pdf

21. Kwilinski, A., Dzwigol, H., \& Dementyev, V. (2020b). Model of Entrepreneurship Financial Activity of the Transnational Company Based on Intellectual Technology. International Journal of Entrepreneurship, 24(Special Issue: Entrepreneurship, Innovation Management and Sustainability), 1-5. Retrieved from https://www.abacademies.org/articles/Model-of-Entrepreneurship-Financial-Activity-of-the-TransnationalCompany-Based-on-Intellectual-Technology.pdf

22. Lakhno, V., Malyukov, V., Bochulia, T., Hipters, Z., Kwilinski, A., \& Tomashevska, O. (2018). Model of managing of the procedure of mutual financial investing in information technologies and smart city systems. International Journal of Civil Engineering and Technology, 9(8), 1802-1812. Retrieved from http://www.iaeme.com/MasterAdmin/UploadFolder/IJCIET 0908 181/IJCIET 0908 181.pdf

23. Leshchenko, O. Y. (2016). Vplyv «suchasnykh voyenno-politychnykh konfliktiv na problematyku tsyvil'noho zakhystu: dosvid Syriyi ta Ukrayiny. Visnyk Dnipropetrovs'koho un-tu. Seriya: «Filosofiya. Sotsiolohiya. Politolohiya», 5, 67-80. [ Leshchenko, O. Y. (2016). The impact of "modern military-political conflicts on the issues of civil defense: the experience of Syria and Ukraine. Bulletin of Dnipropetrovsk 
University. Series: Philosophy. Sociology. Political Science, 5, 67-80]. Retrieved from: http://www.irbisnbuv.gov.ua/cgi-bin/irbis_nbuv/cgiirbis 64.exe?I21DBN=LINK\&P21DBN=UJRN\&Z21ID = \&S21REF=

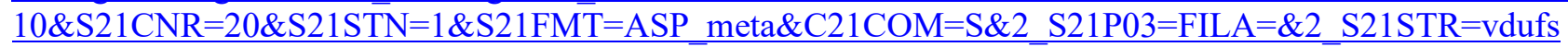
p 20165111

24. Miskiewicz, R. (2017a). Knowledge in the Process of Enterprise Acquisition. Progress in Economic Sciences, 4, 415-432. https://doi.org/10.14595/PES/04/029

25. Miskiewicz, R. (2017b). Knowledge Transfer in Merger and Acquisition Processes in the Metallurgical Industry. Warsaw: PWN.

26. Miśkiewicz, R. (2018). The Importance of Knowledge Transfer on the Energy Market. Polityka Energetyczna, 21(2), 49-62. http://dx.doi.org/10.24425\%2F122774

27. Miśkiewicz, R. (2019). Challenges Facing Management Practice in the Light of Industry 4.0: The Example of Poland. Virtual Economics, 2(2), 37-47. https://doi.org/10.34021/ve.2019.02.02(2)

28. Pająk, K., Kvilinskyi, O., Fasiecka, O., \& Miśkiewicz, R. (2017). Energy Security in Regional Policy in Wielkopolska Region of Poland. Economics and Environment, 2(61), 122-138. Retrieved from https://www.ekonomiaisrodowisko.pl/uploads/eis\%2061/11_pajak.pdf

29. Polityka intehratsiyi ukrayins'koho suspil'stva v konteksti vyklykiv ta zahroz podiy na Donbasi (2015). Natsional'na dopovid'. Kyiv: NAN Ukrayiny, 363. [The policy of integration of Ukrainian society in the context of challenges and threats of events in Donbass (2015). National report. Kyiv: National Academy of Sciences of Ukraine, 363]. Retrieved from: https://www.idss.org.ua/monografii/2016 dopov_Donbas.pdf

30. Sidorova, Y. A. (2008). Kriticheskiy analiz teoriy pryamykh inostrannykh investitsiy. Aktual'nyye problemy sovremennoy ekonomicheskoy nauki: materiali Mezhdunar. regional'noy nauchno-prakt. konf. [Sidorova, E. A. (2008). A critical analysis of theories of foreign direct investment. Actual problems of modern economic science: materials of the Intern. regional scientific and practical. conf.]. Retrieved from: http://www.a-economist.narod.ru/section1/2008-2009/sidorova.htm

31. Snihova, O.Y. (2015). Finansovi ryzyky ta zahrozy v umovakh zbroynoho konfliktu na skhodi Ukrayiny. Hlobal'ni ta natsional'ni problemy ekonomiky, 5, 246-250. [Snihova, O.Y. (2015). Financial risks and threats in the context of the armed conflict in eastern Ukraine. Global and National Economic Problems, 5, 246-250. Retrieved from: http://global-national.in.ua/archive/5-2015/50.pdf

32. Sobkevych, O.V. (2015). Otsinka vtrat ta mekhanizmiv vidbudovy real'noho sektoru ekonomiky Skhodu Ukrayiny, Analitychna zapyska. [Sobkevich OV (2015). Assessment of losses and mechanisms for rebuilding the real sector of the economy of Eastern Ukraine. Analytical note]. Retrieved from: https://niss.gov.ua/\%20public/File/2015_analit/realniy_sector.pdf

33. Stukalo, N. V., Khutorna, A. V. (2012). Dosvid derzhavnoho rehulyuvannya inozemnykh investytsiy u krayinakh svitu. Ekonomika s'ohodennya: aktual'ni pytannya ta perspektyvy: zbirnyk naukovykh prats'. [Stukalo, N.V., Khutorna, A.V. (2012). Experience of state regulation of foreign investments in the world. Today's economy: current issues and prospects: a collection of scientific papers]. Retrieved from: http://economicsissues.com.ua/zmist-zhurnalu/ekonomika-sogodennya-aktualni-pitannya-taperspektivi2012-1/dosvid-derzhavnogo-regulyuvannya-inozemnix-investicij-ukra\%D1\%97nax-svitu/

34. Frolova T.O. (2013). Kontseptual'na model' rozroblennya ta realizatsiyi investytsiynoyi stratehiyi TNK. Ekonomika i pidpryyemnytstvo: zb. nauk. prats' KNEU. Kyyiv, 30. 52-65. [Frolova TO (2013). Conceptual model of development and implementation of investment strategy of TNCs. Economics and Entrepreneurship: Coll. Science. KNEU. Kyiv, 30. 52-65]. Retrieved from: https://ir.kneu.edu.ua/handle/2010/7759?show=full 